\title{
SIMULATION OF FREIGHT TRAFFIC IN THE SEVILLE INLAND PORT
}

\author{
Pablo Cortés ${ }^{*}$ Jesús Muñuzuri, J. Nicolás Ibáñez, José Guadix \\ Departamento de Ingeniería de Organización. Escuela Superior de Ingenieros. Universidad de \\ Sevilla, Spain
}

\begin{abstract}
The Port of Seville is an inland port located in the Guadalquivir River in the south of Spain and it is the unique Spanish inland port. Our research is focused on the simulation of the freight transport process beginning with the movement through the whole estuary of the river and finishing with the vessels arriving to the port dependencies, where the logistic operators' load and unload processes take place.

The simulation presented in the paper is carried out with Arena software and considers all the types of cargo existing in the Seville Port: containers, cereals, cements, scrap, iron and steel and fertilizers. We have simulated the navigation through the Guadalquivir estuary, the lock, the basins and the docks of the port, as well as the logistic activities in the berths. After testing several scenarios, we can state that the facilities of the Port of Seville allow to deal with the incoming logistic flows, except for momentary difficulties in the container traffic. So the improvement measures for the logistic activity must come from other alternative key actions.
\end{abstract}

Keywords: port, logistics, freight traffic, simulation

\section{Introduction}

The Port of Seville is an inland port located in the Guadalquivir River in the south of Spain and near the Gibraltar Strait. It is the unique inland port in Spain and has a channel length of $80 \mathrm{~km}$. The port is located inside the city of Seville and has diverse access facilities as railway, airport and direct motorway. All these aspects highlight the importance of the Seville inland port as intermodal centre. Figure 1 depicts the current aspect of the Port of Seville.

Our research is focused on the simulation of the freight transport process through the estuary and its arrival to the port dependencies including the load/unload processes by the logistics' operators. So, the analysis of the freight transport is in a wide scope. We have not been able to find many scientific references studying simulation of freight transportation in ports. Most of them are inspired in the Baltic tradition, for example, Merkuryev et al. (1998) [1], Merkuryev et al. (2000) [2] and Merkuryeva et al. (2000) [3]. Nevertheless, simulation has been used in a port context for other objectives; examples of this are the layout planning of Bruzzone et al. (1998) [4]; the planning of container terminals of Silberholz et al. (1991) [5], Gambardella et al. (1998) [6], Kim et al. (1999) [7] and Mastrolilli et al. (1998) [8], and the planning of maritime traffic of Köse et al. (2003) [9]. Additionally, Hayuth et al. (1994) [10] presents a simulation model of the activity of maritime ports.

\footnotetext{
* Corresponding author.

E-mail address: pca@esi.us.es (P. Cortes)
} 


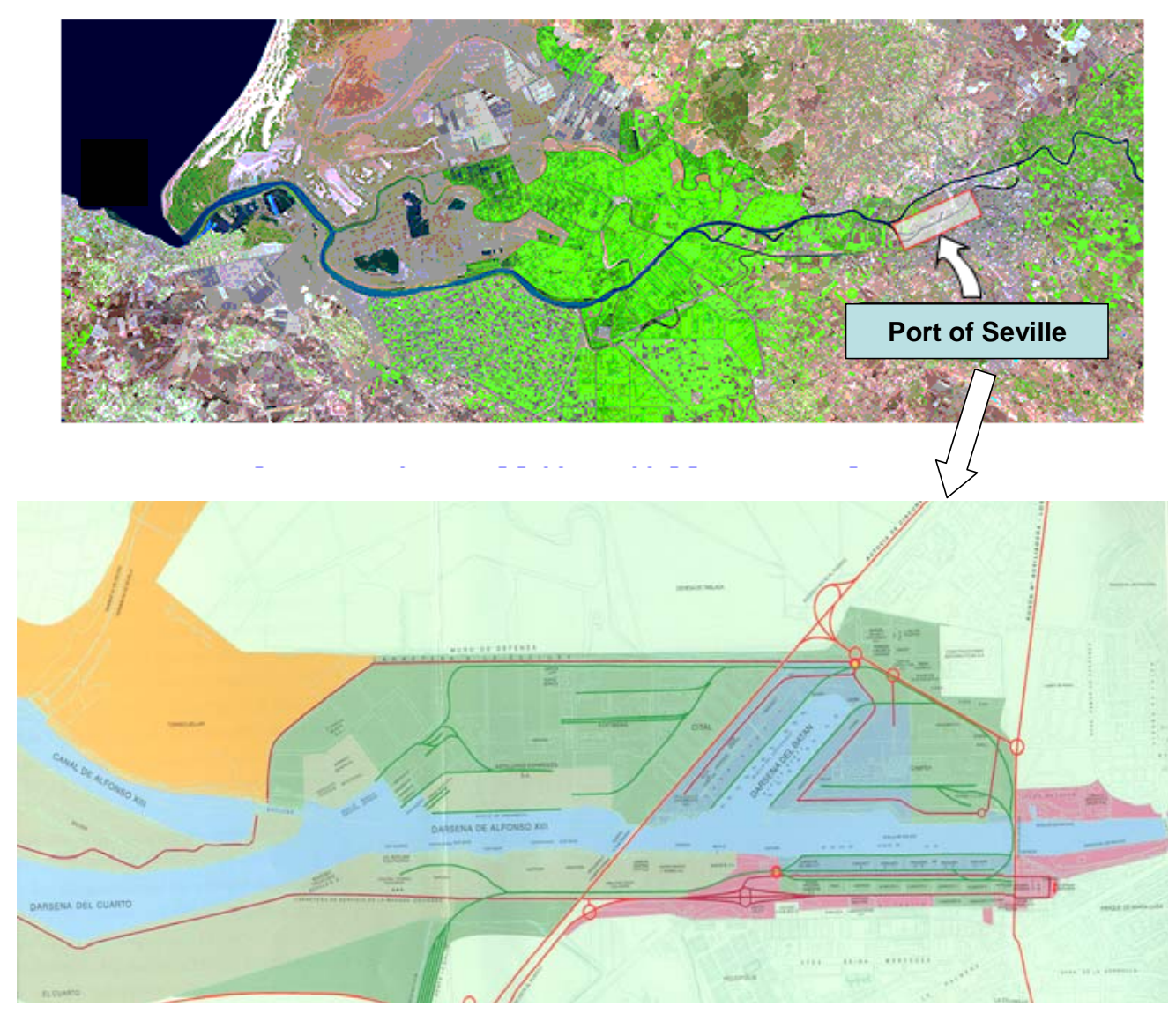

Fig. 1. Satellite image of the Guadalquivir estuary since the mouth of the river to the Port (up) and layout of the Seville Port with its basins and docks (down)

The rest of the paper deals with the simulation scenario and is organized as follows. In section 2 it is presented the estuary navigation conditions and the freight traffic characteristics. A technical description of the simulation is carried out in section 3 and the main simulation results, including the simulation of both independent and real traffic, is showed in section 4 . Finally, section 5 summarizes the main conclusions and final remarks.

\section{Simulation scenario}

The simulation scenario characterizes the Seville inland port (see figure 2). It includes the Guadalquivir estuary, the lock, the basins (Basin of Cuarto, Basin of Alfonso XIII and Basin of Batán) and the docks (Centenario, North Batán and Tablada). Each of the docks has diverse berths (6 for Centenario, 5 for Tablada, and 4 for North Batán). 


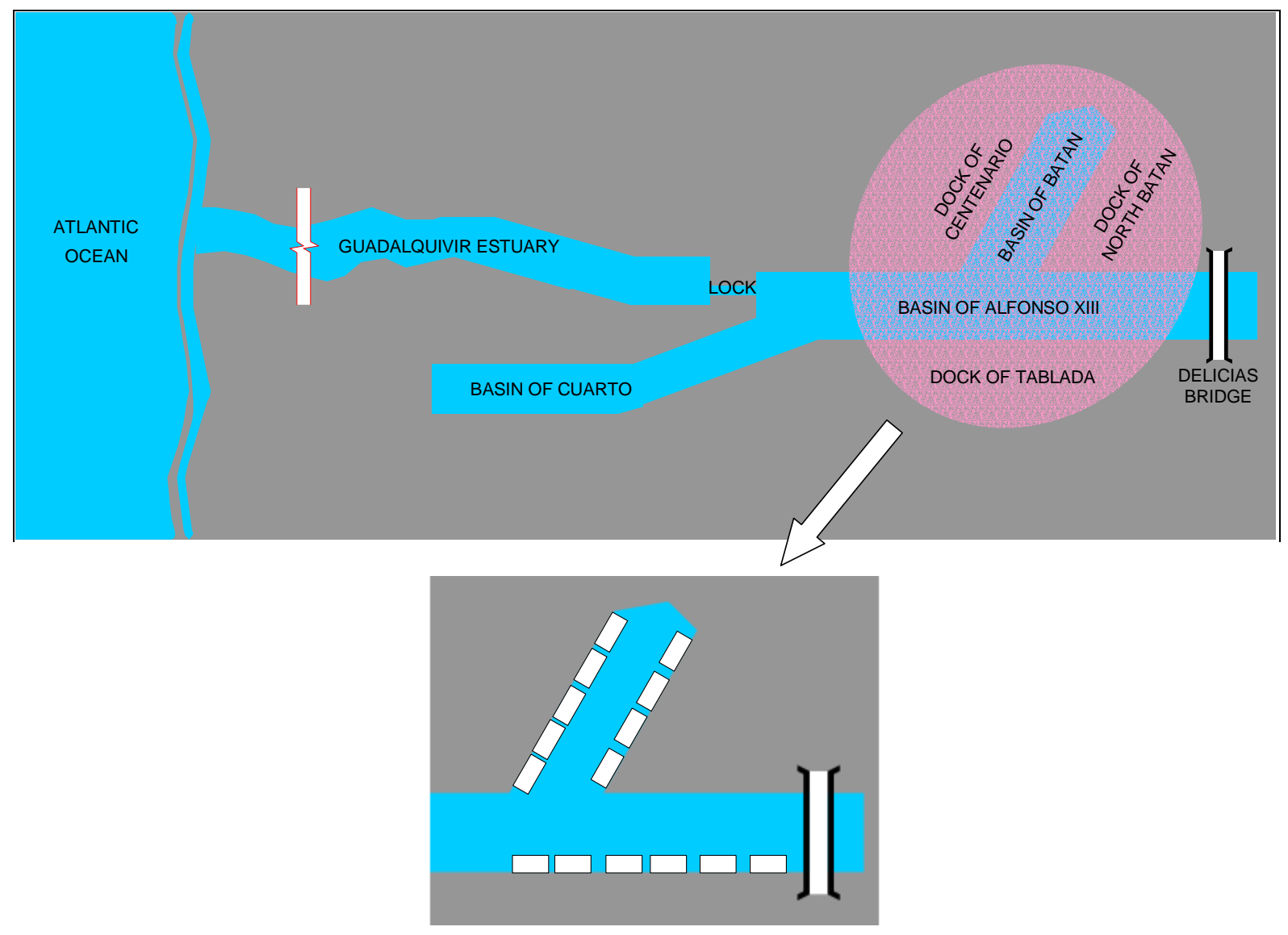

Fig. 2. Simulation scenario

Next we describe the special characteristics of navigation through the Guadalquivir estuary and the freight traffic specifications in the Port of Seville.

\subsection{Estuary navigation and characteristics of the port}

The access channel from the mouth of the river to the port is a 50 mile estuary with a depth of 6 metres.

A lock turns the River Guadalquivir into the harbour. This means the port is not subject to tides and keeps constant water depths. Having passed through the lock the vessel comes across a series of terminals, berths and docks. The technical characteristics of the lock are $200 \mathrm{~m}$ length (with doors locked), 24.36m width and 8m depth, taking around 10-15 min to cross it.

The three main docks of the port depicted previously in Figure 2 are described in table 1. 
Table 1. Characteristics of the Seville Port docks

\begin{tabular}{|c|c|c|c|}
\hline \multicolumn{4}{|l|}{ Centenario dock } \\
\hline Physical characteristics & Cargo type & Dock equipment & Dock surface \\
\hline $\begin{array}{l}\text { Length: } 778 \mathrm{~m} .(53 \mathrm{~m} . \\
\text { Ro-Ro ramp) } \\
\text { Depth: } 7.5 \mathrm{~m} . \\
\text { Width: } 190 \mathrm{~m} .\end{array}$ & $\begin{array}{l}\text { Containers } \\
\text { Ro-Ro } \\
\text { traffic } \\
\text { Cargo in } \\
\text { bulks }\end{array}$ & $\begin{array}{l}5 \text { gantry cranes } 6 \text { t. Performance: } 100 \\
\text { ton/hour (for cargo in bulk) } \\
2 \text { gantry cranes } 16 \text { t. Performance: } 400 \\
\text { ton/hour (for cargo in bulk) } \\
1 \text { container crane } 30 t \text { t. Performance: } 12 \\
\text { cont./hour } \\
1 \text { container crane } 35 \text { t. Performance: } 20 \\
\text { cont./hour } \\
\text { Ro-Ro ramp } \\
12 \text { silos } 1,300 \mathrm{~m}^{3} \text { and } 2 \text { conveyor belts for } \\
\text { oilseeds ('Muñoz Chapuli' facilities) }\end{array}$ & $\begin{array}{l}50 \times 300 \mathrm{~m}^{2} \text { for } \\
\text { containers ( } 4 \text { modules of } \\
120 \text { slots) } \\
40 \times 400 \mathrm{~m}^{2} \text { for solids in } \\
\text { bulk (density } 10 \text { ton } / \mathrm{m}^{2} \text { ) }\end{array}$ \\
\hline \multicolumn{4}{|l|}{ North Batán dock } \\
\hline Physical characteristics & Cargo & Dock equipment & Dock surface \\
\hline $\begin{array}{l}\text { Length: } 667 \mathrm{~m} .(17 \mathrm{~m} . \\
\text { Ro-Ro ramp) } \\
\text { Depth: } 7.5 \mathrm{~m} . \\
\text { Width: } 120 \mathrm{~m} .\end{array}$ & $\begin{array}{l}\text { Ro-Ro } \\
\text { traffic } \\
\text { Cargo in } \\
\text { bulks }\end{array}$ & $\begin{array}{l}3 \text { gantry cranes 6t. Performance: } 100 \\
\text { ton/hour (for cargo in bulk) } \\
3 \text { gantry cranes } 16 t \text {. Performance: } 135 \\
\text { ton/hour (for cargo in bulk) } \\
\text { Ro-Ro ramp } \\
\text { Cement load conduit. Performance: } 80 \\
\text { ton/hour } \\
\text { Covered sheds: } 5,000 \mathrm{~m}^{2} \text { each of them. }\end{array}$ & $\begin{array}{l}40 \times 400 \mathrm{~m}^{2} \text { for solids in } \\
\text { bulk (density } 10 \text { ton } / \mathrm{m}^{2} \text { ) }\end{array}$ \\
\hline \multicolumn{4}{|l|}{ Tablada dock } \\
\hline Physical characteristics & Cargo & Dock equipment & Dock surface \\
\hline $\begin{array}{l}\text { Length: } 1,122 \mathrm{~m} . \\
\text { Depth: } 7.5 \mathrm{~m} . \\
\text { Width: } 72 \mathrm{~m} .\end{array}$ & $\begin{array}{l}\text { Cargo in } \\
\text { bulks }\end{array}$ & $\begin{array}{l}2 \text { gantry cranes } 12 \text { t. Performance: } 200 \\
\text { ton/hour (for cargo in bulk) } \\
4 \text { gantry cranes } 8 t \text { t. Performance: } 170 \\
\text { ton/hour (for cargo in general) } \\
1 \text { conveyor belt for cement. Performance: } \\
250 \text { ton/hour } \\
2 \text { uncovered sheds and } 3 \text { covered sheds: } \\
4,400 \mathrm{~m}^{2} \text { each of them. }\end{array}$ & $\begin{array}{l}40 \times 400 \mathrm{~m}^{2} \text { for solids in } \\
\text { bulk (density } 10 \text { ton } / \mathrm{m}^{2} \text { ) }\end{array}$ \\
\hline
\end{tabular}

Regarding the analysis of the simulation made in this paper of the navigation in the river estuary and within the port, the most significant aspects are the potential bottlenecks; these could be the depth of the estuary, the breadth and length of the lock, the coastal pilots, the dock facilities and the mooring rope workforce.

There are 14 coastal pilots (they are responsible of piloting the vessel into the estuary and the port), half of them working from midnight to noon and the other half during the rest of the day. Also, there exists a mooring rope workforce of 5 people and 2 of them are necessary to carry out the operations in each vessel.

\subsection{Freight traffic description}

The freight traffic data used in the simulation are based on the annual reports of the Port Authority of Seville and show that more than $92 \%$ of the total traffic is freight-type. Table 2 characterizes this freight. 
Table 2. Guadalquivir estuary freight traffic composition

\begin{tabular}{|l|l|r|r|}
\hline \multicolumn{1}{|c|}{ Cargo } & \multicolumn{1}{c|}{ Dock } & $\begin{array}{c}\text { Number of } \\
\text { vessels }\end{array}$ & $\begin{array}{r}\text { Percentage of } \\
\text { vessels (\%) }\end{array}$ \\
\hline Containers & Centenario & 83 & 33.74 \\
\hline Cements & North Batán & 18 & 19.11 \\
\hline Cereals & Centenario & 47 & 7.32 \\
\hline Scrap & North Batán & 16 & 6.50 \\
\hline Scrap & Tablada & 12 & 4.88 \\
\hline Iron and steel & Centenario & 11 & 4.47 \\
\hline Iron and steel & North Batán & 9 & 3.67 \\
\hline Cereals & Tablada & 9 & 3.67 \\
\hline Fertilizers & Tablada & 9 & 3.67 \\
\hline Fertilizers & North Batán & 6 & 2.44 \\
\hline Iron and steel & Tablada & 3 & 1.22 \\
\hline
\end{tabular}

(1) The data corresponds to the first four-month period of 2003. It is a representative period and it has been assumed as basis for the analysis.

Source: Annual report of the Seville Port for 2003, (2004)

The container vessels are routed to the container terminal: berths 1 and 2 in the Centenario dock, depending on the freight proprietary company (Contenemar, TMS or Pinillos). The containers delivered by the vessels or lorries are left in the container terminal of each company. Each terminal has an average capacity of 700 TEUs (approx. 520 containers using a 1.35 TEUs/container coefficient). The gantry cranes for containers (cranes number 1 and 2) have a 30 container/hour performance.

The cereal vessels are routed to berths 3 and 4 in the Centenario dock and the berths 3 and 4 in Tablada dock. If vessels are empty they are routed to Centenario dock, otherwise it can be assigned to any berth in both docks, though with major probability to the Tablada dock ones (in case this dock was busy, the vessel is routed to the other one). According to data published by the Authority of the Port of Seville and own calculations, the amount of cereals cargo using the port fits well to a normal distribution with a mean of 3,000 and a standard deviation of 800 tons per vessel. The vessels berthing in Centenario dock leave the cargo in the cereals silos of 'Muñoz Chapuli' Company (with a capacity equal to 12,000 tons), whilst the vessels berthing in Tablada dock leave the cargo in the dock sheds with a capacity equal to 110,000 tons. The cargo is stored in the silos according to a normal distribution with a mean of 20 days and a standard deviation of 4 days.

The scrap vessels are routed to berths 3 and 4 in the North Batán dock and berths 5 and 6 in Tablada dock. The dock assignment follows the next procedure: if all the berths are available, the vessel that arrives first is routed to berth 4 in North Batán dock, the second to berth 6 in Tablada dock, the third to berth 3 in North Batán dock and the last one to berth 5 in Tablada dock, i.e., they are assigned to alternative berths in alternative docks. The cargo per vessel follows a normal distribution with a mean of 3,000 tons and 700 as standard deviation. The scrap is left on uncovered facilities in both docks, being the total capacity equal to 36,000 tons in each dock. The time for the cargo stored follows a normal distribution with a mean of 6.5 days and a standard deviation equal to 2 days.

The vessels transporting iron and steel are routed to the berth 5 in the Centenario dock, which is exclusively dedicated for this type of freight. In case this dock was busy, the vessel is 
routed to the berth 4 of Centenario dock, 3 of North Batán dock or 5 of Tablada dock, following this order. All of them are docks without exclusive dedication. The cargo per vessel is normal with a mean of 3,500 tons and standard deviation of 800 tons. The iron and steel products are put away in uncovered dock stores during a time just as in the scrap case. The storing capacity is equal to 50,000 tons.

The vessels transporting cement are routed to the berths 1 and 2 in North Batán dock. If the two are free the vessel is assigned to berth 1 . The cement cargo is normal with mean equal to 4,500 and standard deviation equal to 1,500 tons per vessel. The cement is unload into silos owned by 'Asland' company, which a capacity of 7,500 tons per silo (the company has two silos).

The vessels transporting fertilizers are routed to the berth 2 in North Batán dock. If the dock is busy, the cargo is routed to the berths 1 and 2 in Tablada dock. The cargo transported per vessel is normal with a mean of 3,000 tons and a standard deviation of 700. In the North Batán dock, the cargo is unloaded and put away on uncovered storing facilities (the same as with scrap and iron and steel). On the other hand, the cargo unloaded in the Tablada docks requires for the process a time equivalent to that of the cereals unloading process.

Table 3 shows the performance of the 18 cranes involved in the port activity and classified by the cargo they handle.

Table 3. Performance of the cranes depending on the type of cargo

\begin{tabular}{|c|c|c|c|}
\hline Cargo & Dock - Berth & Crane & $\begin{array}{c}\text { Performance } \\
\text { (ton/hour) }\end{array}$ \\
\hline \multirow{6}{*}{ Cereals } & \multirow{2}{*}{ Centenario - 3} & C3a & 100 \\
\hline & & C3b & 300 \\
\hline & \multirow{2}{*}{ Centenario - 4} & $\mathrm{C} 4 \mathrm{a}$ & 300 \\
\hline & & $\mathrm{C} 4 \mathrm{~b}$ & 100 \\
\hline & \multirow{2}{*}{ Tablada - 3 and 4} & T3 & 170 \\
\hline & & $\mathrm{T} 4$ & 170 \\
\hline \multirow{6}{*}{ Scrap } & \multirow{2}{*}{ North Batán - 3} & B3a & 135 \\
\hline & & B3b & 100 \\
\hline & \multirow{2}{*}{ North Batán - 4} & B4a & 100 \\
\hline & & B4b & 100 \\
\hline & \multirow{2}{*}{ Tablada -5 and 6} & T5 & 200 \\
\hline & & T6 & 200 \\
\hline \multirow{2}{*}{ Iron and steel } & \multirow{2}{*}{ Centenario - 5} & $\mathrm{C5a}$ & 100 \\
\hline & & $\mathrm{C} 5 \mathrm{~b}$ & 100 \\
\hline \multirow{2}{*}{ Cement } & \multirow{2}{*}{ North Batán - 1 and 2} & $\mathrm{~B} 1$ & 135 \\
\hline & & $\mathrm{B} 2$ & 135 \\
\hline \multirow{2}{*}{ Fertilizer } & \multirow{2}{*}{ Tablada -1 and 2} & $\mathrm{~T} 1$ & 170 \\
\hline & & $\mathrm{T} 2$ & 170 \\
\hline
\end{tabular}




\section{Logical and technical description of the simulation}

The simulation of the freight traffic in the estuary and within the port was carried out using ARENA software. We show in Figure 3 the layout of the animation screen of this simulation. The model that is built is composed of the following main elements: the vessel arrival, the dock assignment, the vessel departure, the lorry arrival and departure, the container terminal, the 'Asland' company facilities for cement, the 'Muñoz Chapuli' company facilities for cereals and the rest of docks that are dealt in a uniform way.

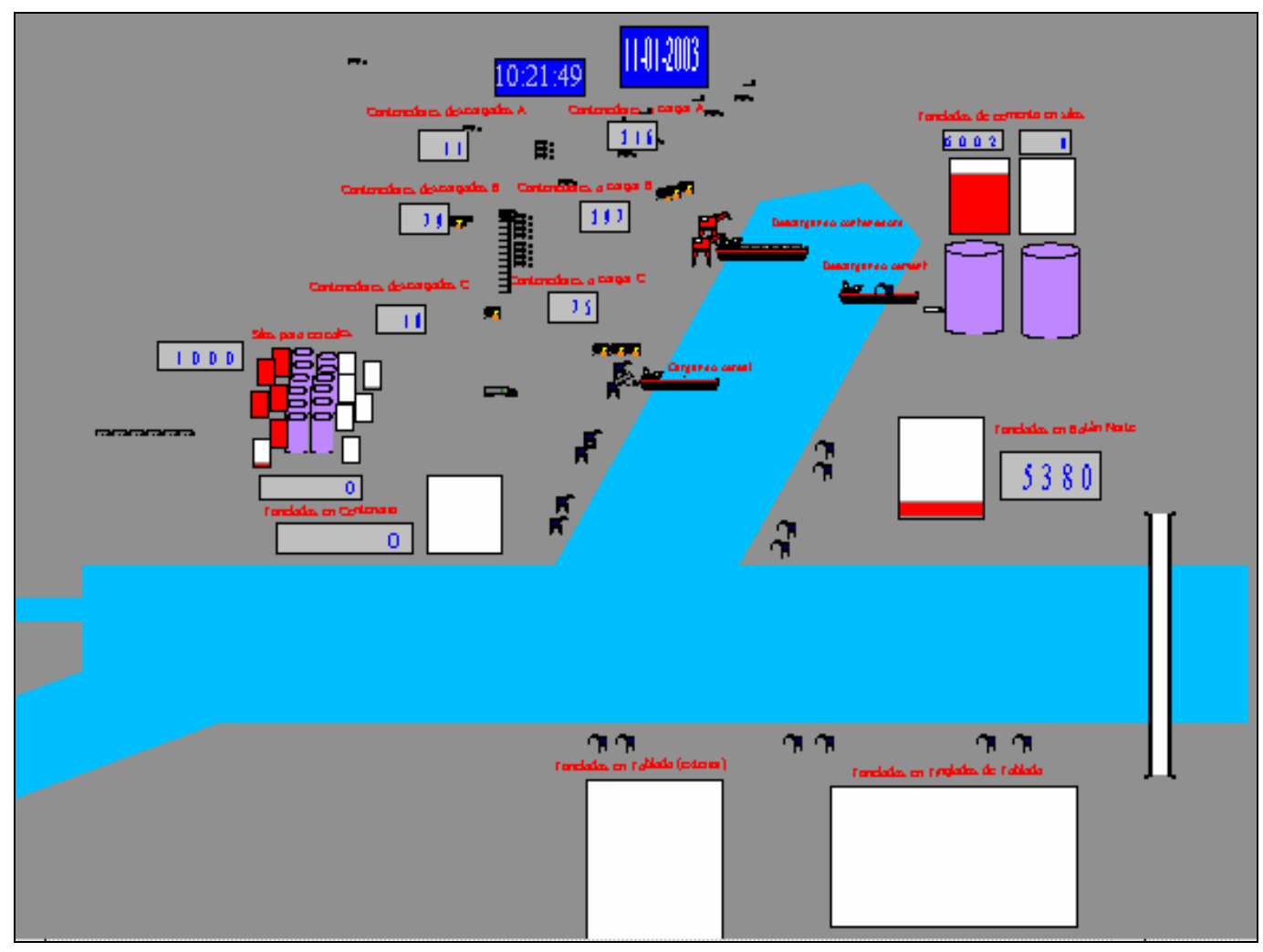

Fig. 3. Snapshot of the simulation animation

Each of these elements are described separately in the ensuing sections and according to the specifications of the Operative Procedures Manual of the Seville Port [11] and the General Management Plan for the Port of Seville [12].

\subsection{Vessel arrival}

The vessel arrives to the system through the Guadalquivir estuary (modelled by means of a module 'Create'), occupying a resource coastal pilot. Afterwards, it moves on towards the lock in order to pass through it and access the basin (module 'Route' spending an exponential distribution with rate 5 hours). Once the vessel leaves the lock, the ship goes to the dock assigned as function of its cargo (module 'Decide'). See section 2 for options.

Special attention is paid to the container type vessels. Where a probabilistic module 'Decide' routes the vessel to the proper module 'Assign', where the container transport company is assigned. Table 4 describes the probabilistic container destination according to the statistics from the Annual Report of the Seville Port [13]. Figure 4 depicts the vessel arrival modules. 
Table 4. Probabilistic container destination

\begin{tabular}{|c|l|c|}
\hline Company code & \multicolumn{1}{|c|}{ Company } & Weekly vessels \\
\hline 1 & Contenemar & 1 \\
\hline 2 & TMS & 1 \\
\hline 3 & Pinillos & 2 \\
\hline 4 & Shared Contenemar and Pinillos & 1 \\
\hline
\end{tabular}

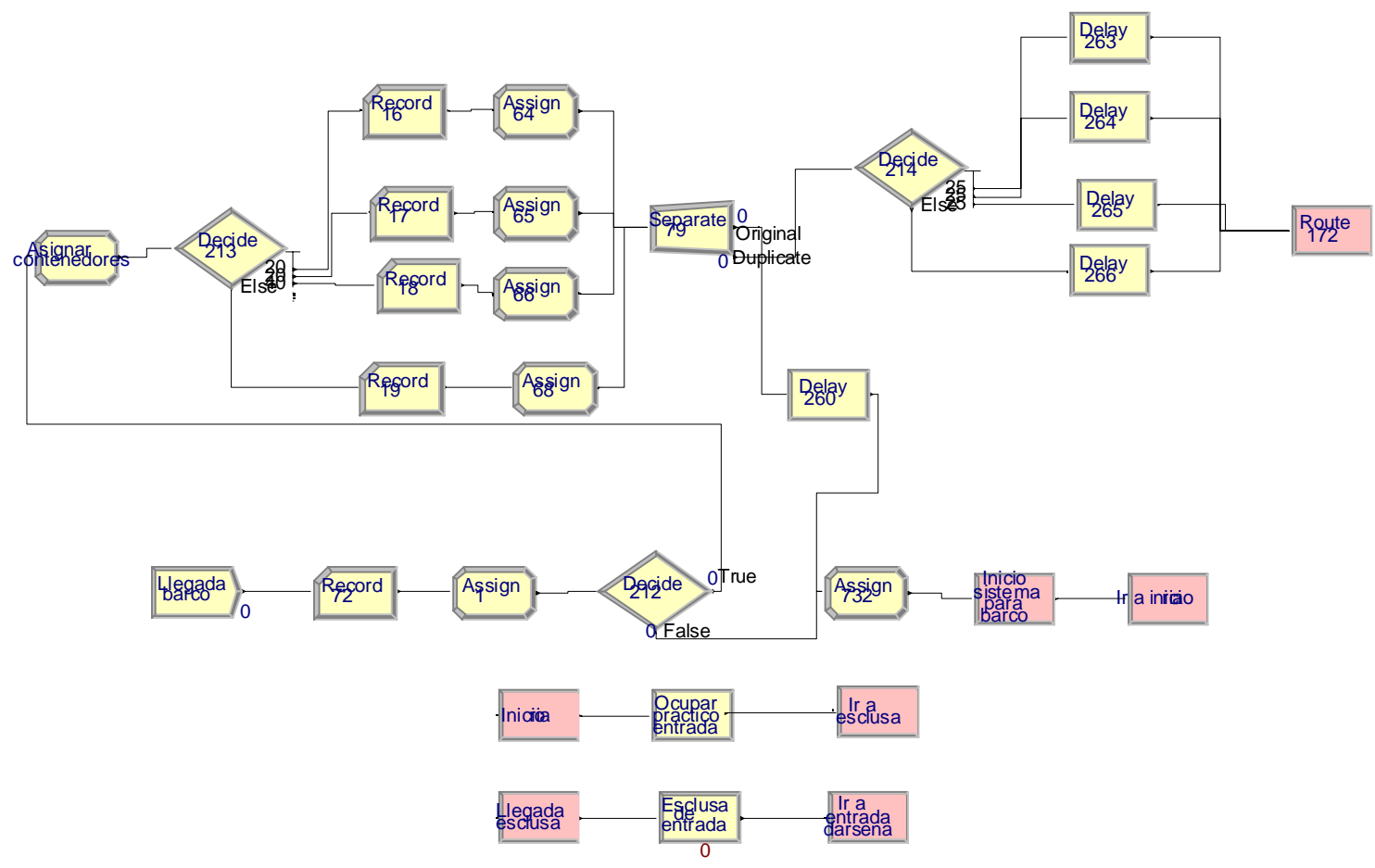

Fig. 4. Vessel arrival modules

\subsection{Dock assignment}

The dock is assigned depending on the type of vessel cargo. The vessel has a number of tons assigned if the cargo is in bulks. The dock selection criterion is to choose that with the lower queue. The transfer time is exponentially distributed with rate of 0.6 hours.

For the container type vessels, the cargo is generated in the previous module and is routed to the dock depending on the property of the cargo. Next figure shows the dock assignment modules. 


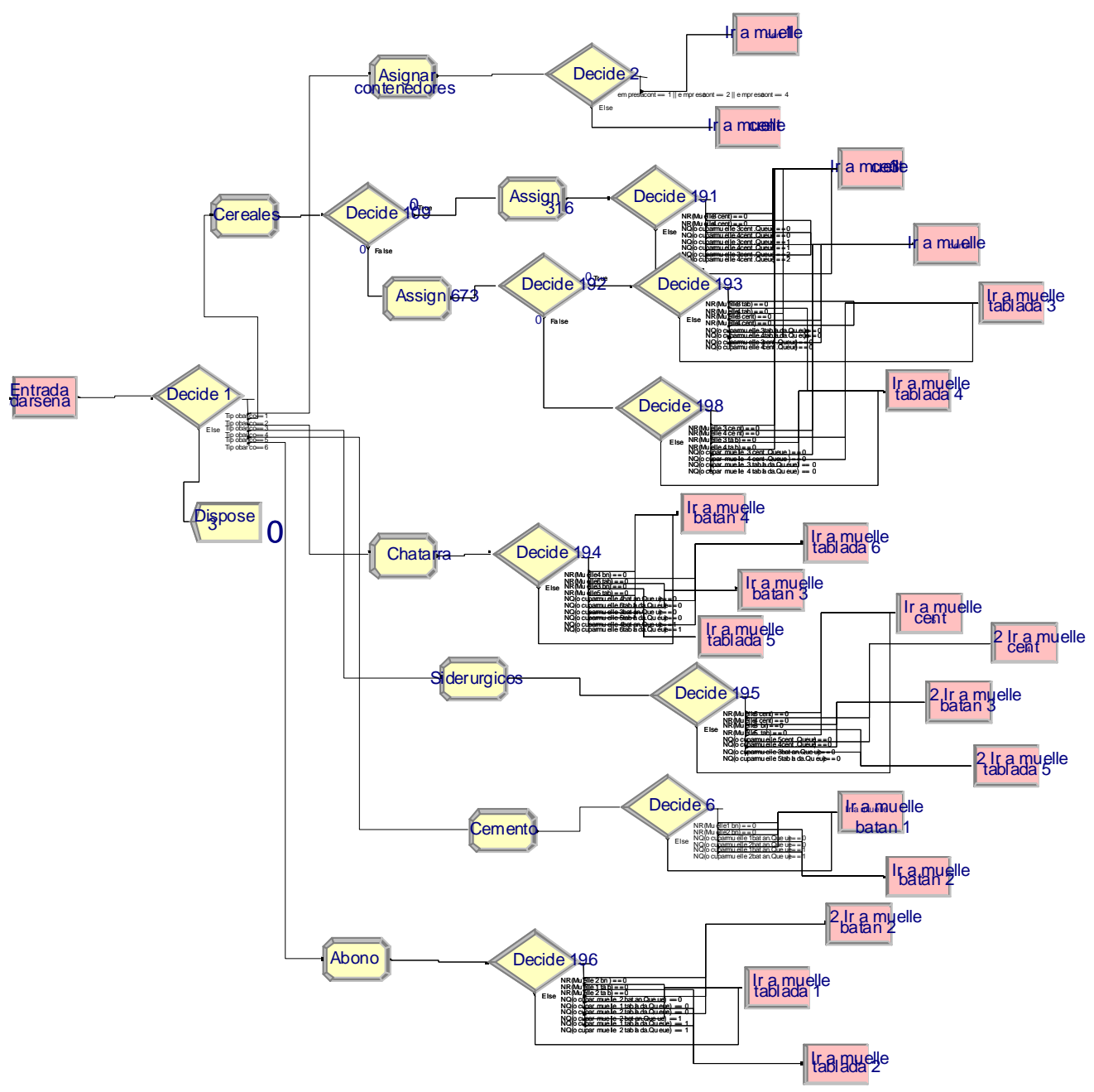

Fig. 5. Dock assignment modules

\subsection{Vessel departure}

Once the vessel leaves the dock it starts its way back to the Atlantic Ocean. Firstly, the vessel is routed to the lock, being its passing through it simulated in the same way as in the arrival process. Secondly, the vessel continues along the Guadalquivir estuary until reaching the Ocean, liberating the coastal pilot resource before leaving the system by means of a 'Dispose' module, Next figure depicts the vessel departure modules. 

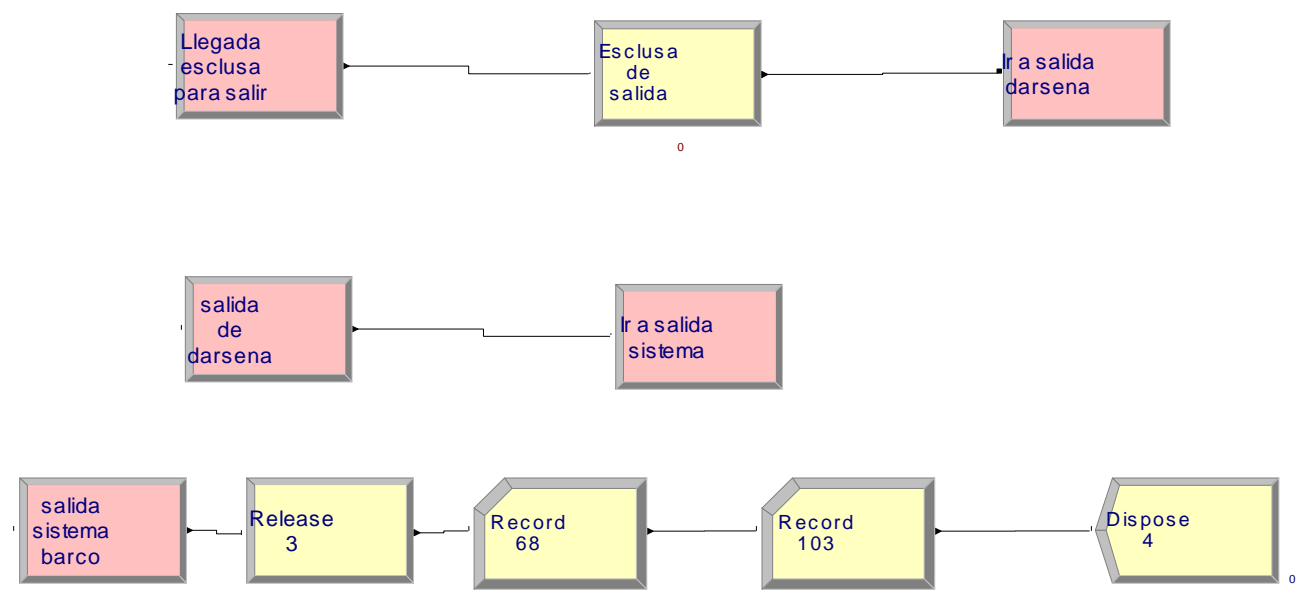

Fig. 6. Vessel departure modules

\subsection{Lorry arrival and departure}

There are three types of lorries: container, cereal and cement lorries. The cement lorries arrives empty and load the cement in the designated port facilities, whilst the cereal and container lorries can also arrive loaded. The loaded lorries arrival linked to the existence of a vessel waiting.

The lorries traffic to and fro the port presented in this section includes the movement of cement of the Asland company (see section 3.6) and the movement of cereals of the Muñoz Chapuli company (see section 3.7). The lorries arrival follows an strict timetable (only at 8.00h and 19.00h from Monday to Friday).

In our simulation process, the lorry arrival is created by means of a module 'Create' and its routing to the specific destination in the port according to the description in section 2.2 by a module 'Decide'. The following figure shows the lorry arrival modules. An equivalent structure is associated for the lorry departure modules. 


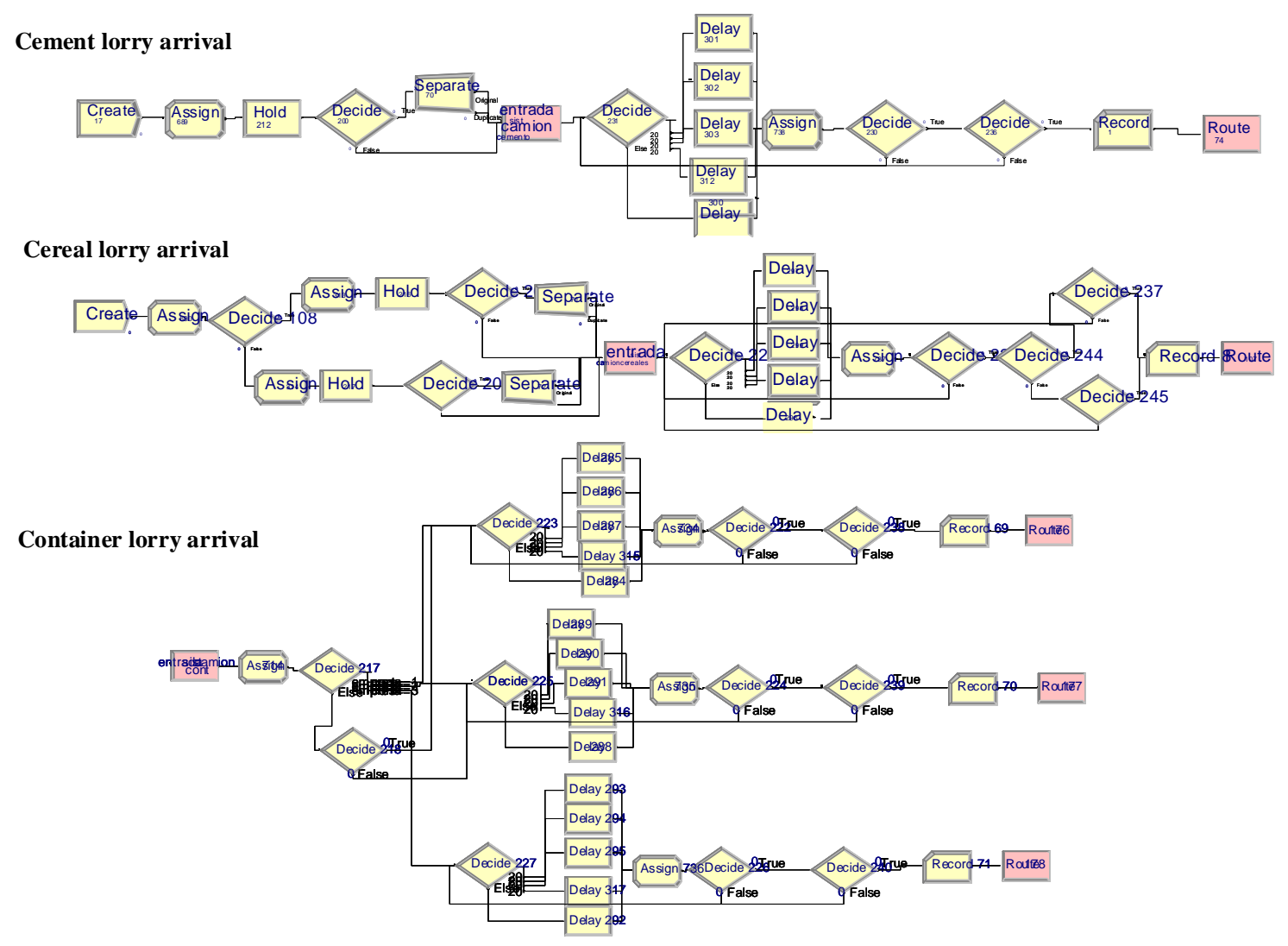

Fig. 7. Lorry arrival modules

\subsection{Container terminal}

There are three companies in the container terminal. Each of them has its own warehouses and machinery. Contenemar and TMS have been assigned by the Port Authority the berth 1 of Centenario dock and Pinillos the berth 2 in the same dock.

The vessel loading process starts with the vessel occupying the dock. Next the mooring rope process starts, using the two elements in the resource mooring rope workforce. At this point the coastal pilot is liberated. Before starting the load or unload process the counters of containers are reset and the availability of gantry cranes tested (each vessel can use either one or two cranes). If the containers are being unloaded they are left on the dock and road-type transport is requested to the proper company to move them out of the part. On the other hand, if they are being loaded into the vessel, firstly the cargo is identified in order to transport the freight to the dock berth by means of fork-lift trucks belonging to the company proprietary of the containers, and secondly, the containers are loaded in the vessel by means of the gantry cranes.

Either following a load or unload process, the vessel leaves the dock once a coastal pilot and mooring rope workforce have been assigned. Finally, the vessel liberates the workforce and the dock and is routed to the lock.

The logistic activity that takes place in the container terminal is different depending if the containers are to be loaded into the vessels (A) or unloaded from them (B): 
A. The containers are transported to the container terminal by lorries of the proper company (Contenemar, TMS or Pinillos). The lorries wait for free fork-lift to move the containers to the company warehouses. Afterwards, once the vessel berths, a free fork-lift truck loads the container into the vessel with the help of the gantry crane.

B. The containers are stored on the surface of the dock that corresponds to each company (Contenemar, TMS or Pinillos) and are kept there until lorries of a certain logistic company move them out of the port.

As an example, Figure 8 depicts the berth 1 of Centenario dock modules. Figure 9 shows the container terminal for a company case.

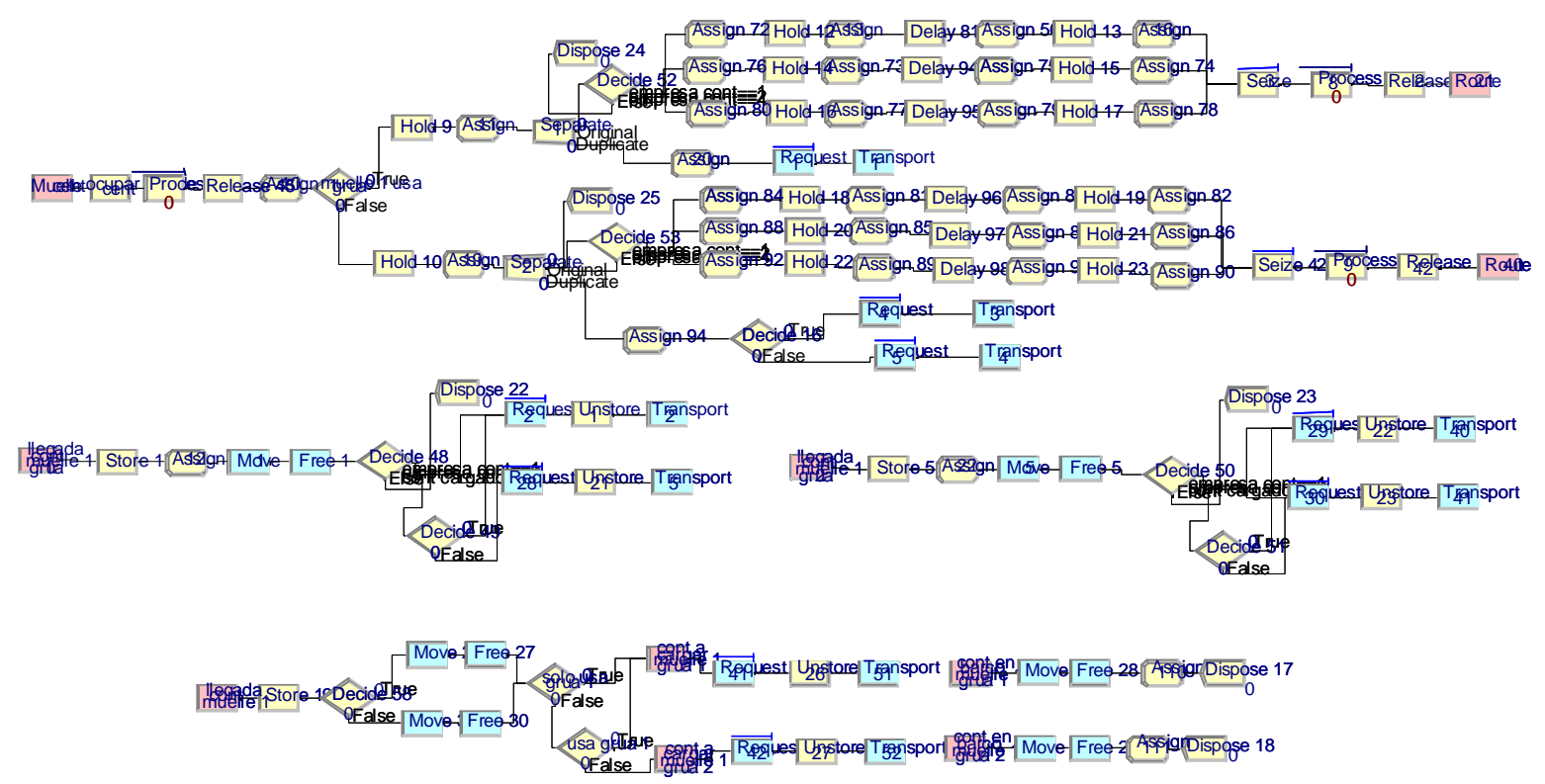

Fig. 8. Berth 1 of Centenario dock modules 


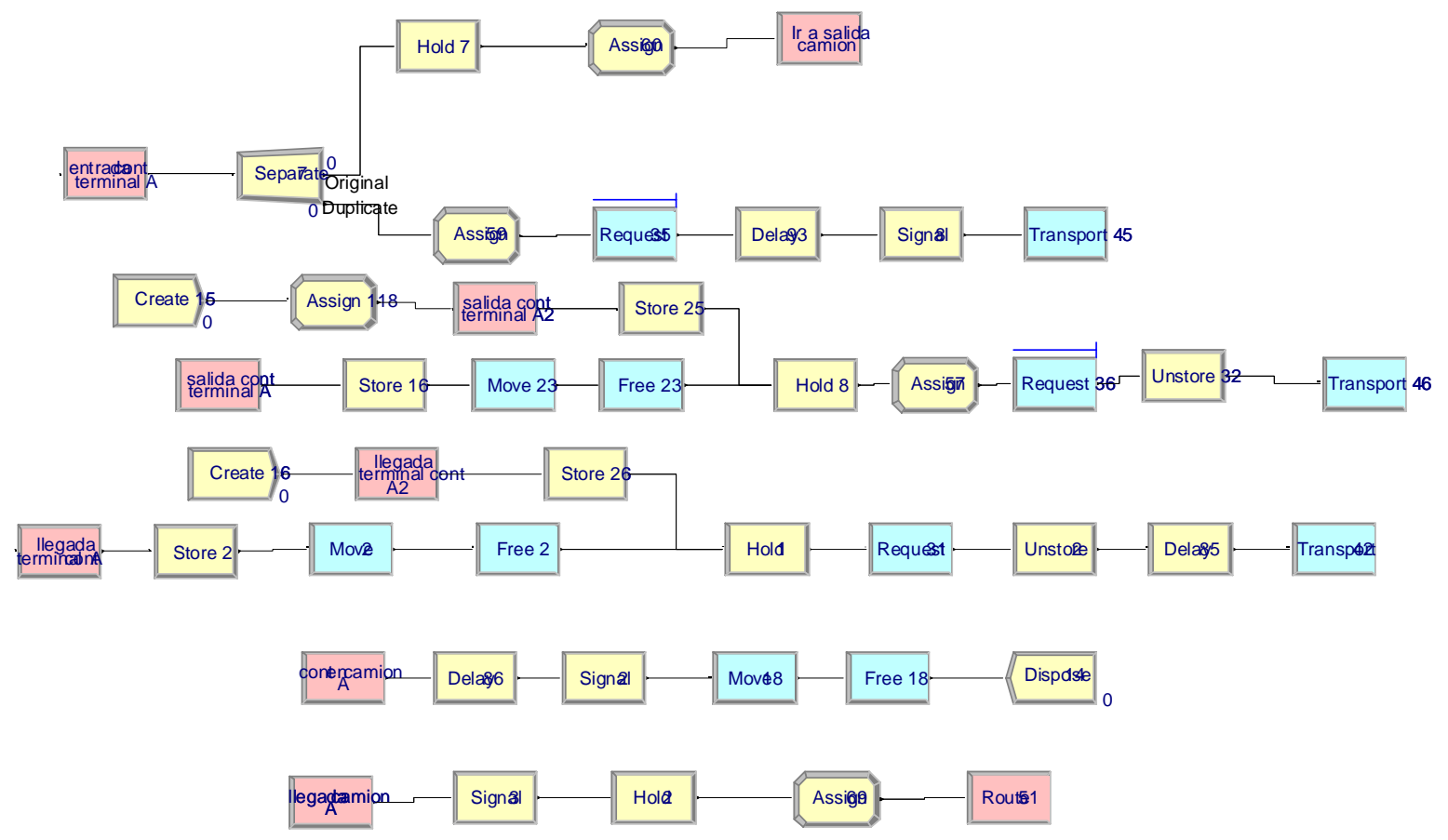

Fig. 9. Container terminal for a company case modules

\section{6. 'Asland' company facilities (cement)}

The 'Asland' company has facilities in the Seville Port (berths 1 and 2 in North Batán dock) to carry out the movement of cement, though berth 2 can also be used to unload fertilizers by other company. The vessels arriving at these berths transport huge amounts of cement making necessary the use of two gantry cranes. The process starts occupying the dock and two people from the mooring rope workforce. After that the coastal pilot is liberated.

The discrete process of the unload process supposes loads of 10 tons. Then the cement is transported to the silos. When the unload process has finished, a module 'Delay' is considered for cleaning activities in the vessel. Next the vessel leaves the basin, once a coastal pilot is assigned, and the dock resource becomes free.

The logistic process associated to the cement lorries is simulated by means of a lorries' queue waiting for loading the cargo in the warehouse. This process reduces the level of cement in the silos. Then the lorry leaves the port facilities.

The performance for the vessels transporting fertilizers is similar to the cement one. The fertilizers entities are loaded with the same two cranes. The fertilizers cargo is loaded by lorries in the warehouses.

Next figure shows the cement 'Asland' Company facilities and the fertilizers logistic process in North Batán dock (berth 2) modules. 


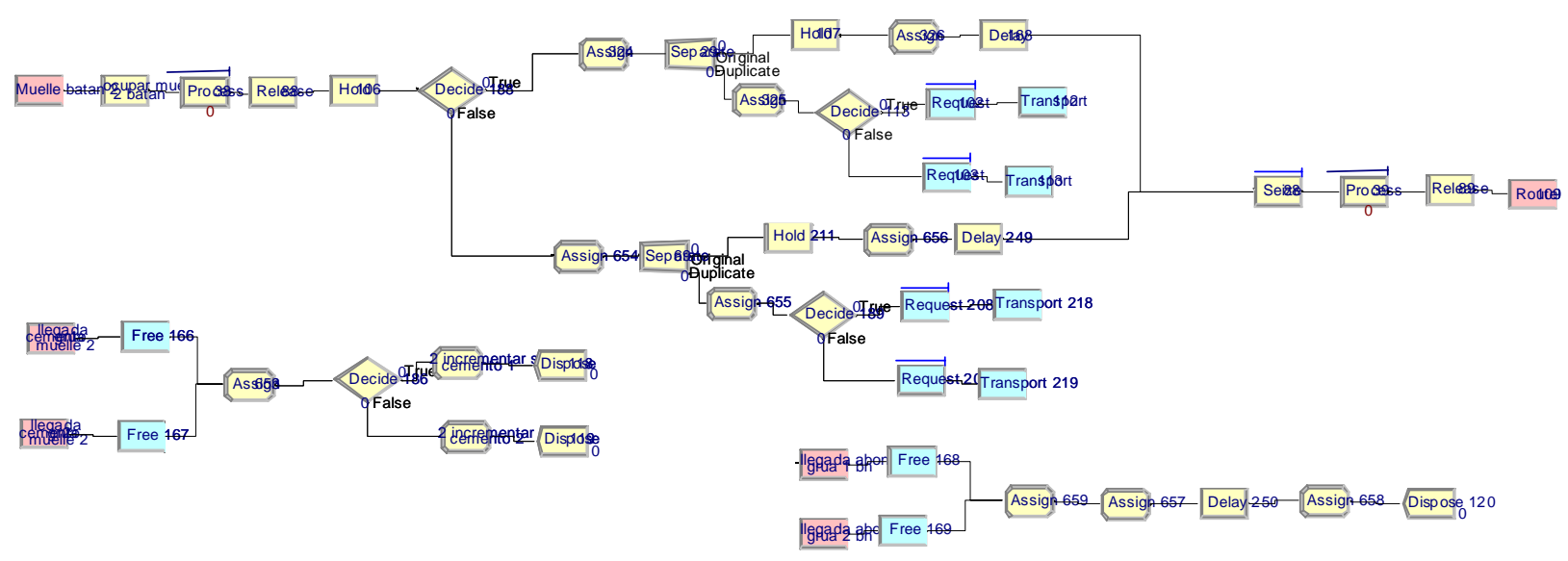

Fig. 10. Cement 'Asland' Company facilities and the fertilizers logistic process in North Batán dock

\section{7. 'Muñoz Chapuli' company facilities (cereals)}

The 'Muñoz Chapuli' company has facilities in the Seville Port to carry out the movement of cereals, specifically the berths 3 and 4 in Centenary dock between the container terminal and the iron and steel facilities. In berth 4 operations related to iron and steel can also take place.

There exists two cranes in each berth, though the four of them can be used simultaneously in the same berth.

When the vessel berths the dock, the dock changes to busy and two people from the mooring rope workforce are required. After this sequence the coastal pilot is liberated, the vessel cargo is unloaded using the cranes and the cereals are transported to the silos.

In case the cereal vessels arrive empty, these are loaded with the cereals stored in the company's silos. The process is carried out by a conveyor belt that moves the cereals from the silo to the vessel according to the stowage plan.

The logistic operators lorries arrive to the company facilities to load or unload cereals. The lorries (with an average capacity for 25 tons of cereals) queue in order to complete the operation.

We mentioned before that iron and steel vessel could also occupy berth 4 . In this case there is no loading on board with a conveyor belt given the notorious differences between commodities. The rest of logistic operations are similar in both cases, storing the unload freight in the proper warehouses of the Centenario dock.

The following figure depicts the Centenario dock (berth 3) performance modules. 


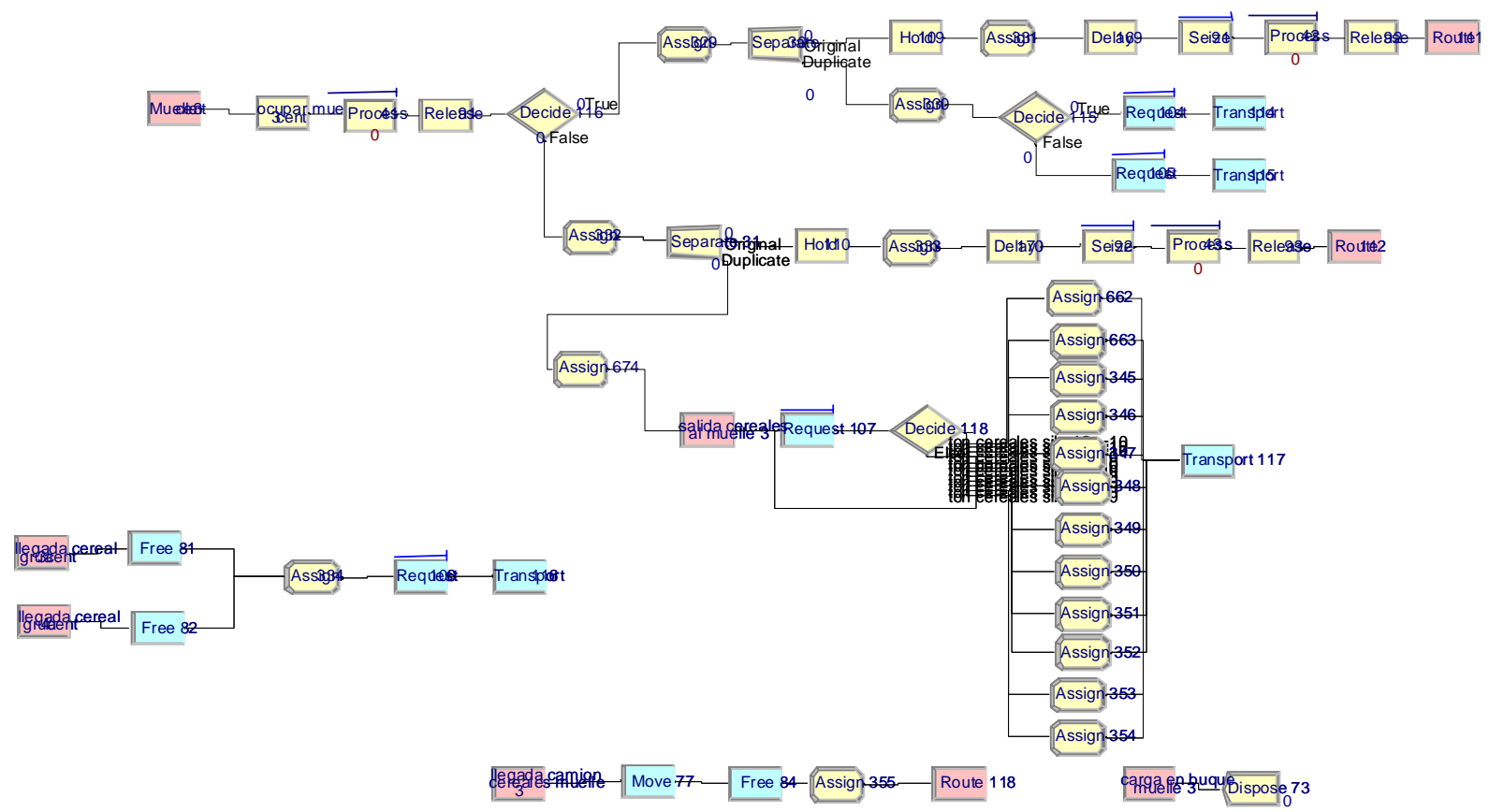

Fig. 11. Cereal 'Muñoz Chapuli' Company facilities and the iron and steel logistic process in Centenario dock

\subsection{Rest of berths}

So far we have not made any reference to the whole Tablada dock (berths 1 to 6 ), berth 5 in the Centenario dock and berths 3 and 4 in the North Batán dock. These have not special facilities and the loading/unloading operations take place in them as follows: Firstly, as the vessel berths, the dock changes to busy along with the mooring rope workforce and the cranes, freeing afterwards the coastal pilot. Later the cargo is unloaded from or loaded into the vessel. Finally, the vessel leaves the dock and the coastal pilot resource is required.

Figure 12 shows the Tablada dock (berth 5) as an example of the "rest of docks" modules.
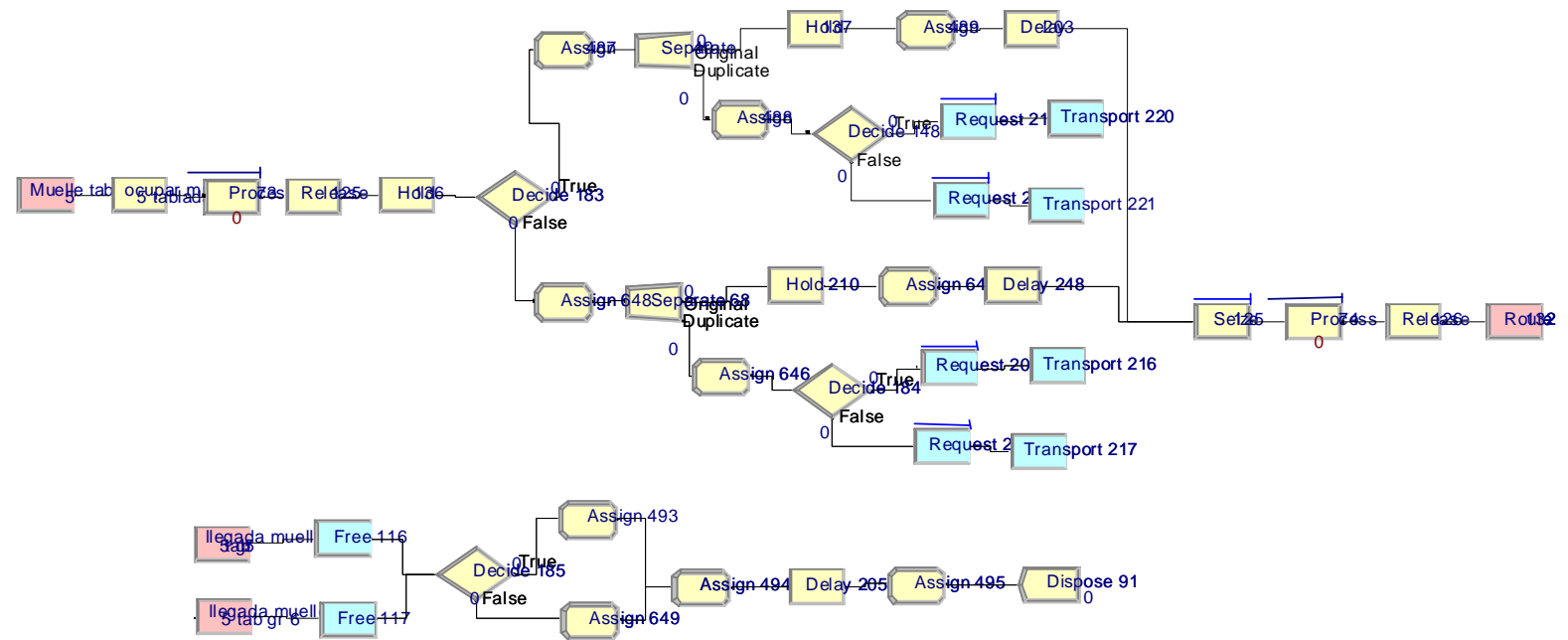

Fig. 12. Tablada dock (berth 5) modules 


\section{Simulation results}

The simulation of the model presented across the previous sections allows the assessment of the main logistic parameters describing Seville Port performance. The variables considered for this assessment are the following:

- Vessel time in the system. The vessel system time is calculated as the time between the arrival of the vessel in the estuary and the exit of the vessel to the Atlantic Ocean. The variable is used to compare different types of traffic and maximum and average values for the variable are used.

- Vessel time in the dock. Time gap between vessel's berthing and departure. The variable includes the queuing time for a free berth.

- Maximum and average values of the following variables (North Batán, Centenario and Tablada are the three docks being analyzed):

$>$ North Batán uncovered warehouse usage (tons). The maximum capacity is 36,000 tons.

$>$ Centenario uncovered warehouse usage (tons). The maximum capacity is 50,000 tons.

> Tablada uncovered warehouse usage (tons). The maximum capacity is 36,000 tons.

$>$ Tablada sheds usage (in tons). The maximum capacity is 110,000 ton.

$>$ Cement silos filling rate (in tons). The maximum capacity is 7,500 tons for each of the two silos property of 'Asland' company.

$>$ Cereal silos filling rate (in tons). The maximum capacity is 1,000 tons for each of the twelve silos property of 'Muñoz Chapuli' company.

$>$ Containers ${ }_{i}$. Number of containers stored in the terminal belonging to company $i$ (Contenemar, TMS or Pinillos). It indicates the containers to be loaded and the containers unloaded at any given time.

- Counters for the following elements:

$>$ Cement lorries with destination 'Asland' company facilities.

$>$ Cereal lorries with destination 'Muñoz Chapuli' company facilities.

$>$ Container lorries $i$ with destination the container terminal $i$ (Contenemar, TMS or Pinillos).

- Queue values for the following resources:

$>$ Docks and berths

$>$ Coastal pilots

$>$ Mooring rope workforce

$>$ Lock

These values provide a logistic picture of the Seville Port performance. Notice that the gantry cranes analysis is linked to the dock and berth one through the berth occupation study. For this reason, the cranes performance is included in the analysis proposed for docks and berths.

The next tables’ time results are expressed in hours.

\subsection{Independent traffic analysis}

It is considered traffic with different cargos, but considered in an individual way. It is considered only the arrival of one vessel type per dock. We try to find average values for the 
vessel system time. As there are not queues for these cases we have an adequate basis of comparison.

We did sixteen simulations for the container traffic. The simulations where done for each type of vessel. They are four types one per company and the type four that is shared by companies one and two). The variations that can be observed are due to the utilisation of one or two gantry cranes. Table 5 shows the results.

Table 5. Dock time for container vessels

\begin{tabular}{|c|c|c|c|c|c|c|c|}
\hline \multirow{2}{*}{$\begin{array}{c}\text { Type of } \\
\text { container } \\
\text { company }\end{array}$} & Dock - Berth & \multicolumn{4}{|c|}{ Replication number } & \multirow{2}{*}{$\begin{array}{c}\text { Average } \\
\text { value }\end{array}$} & $\begin{array}{c}\text { Standard } \\
\text { deviation }\end{array}$ \\
\cline { 3 - 7 } & & $\mathbf{1}^{\text {st }}$ & $\mathbf{2}^{\text {nd }}$ & $\mathbf{3}^{\text {rd }}$ & $\mathbf{4}^{\text {th }}$ & 18.21 & 0.49 \\
\hline 1 & Centenario 1 & 17.82 & 18.31 & 18.87 & 17.86 & 18.21 & 0.46 \\
\hline 2 & Centenario 1 & 17.56 & 18.32 & 18.63 & 18.33 & 18.21 & 0.54 \\
\hline 3 & Centenario 2 & 18.99 & 18.43 & 18.91 & 17.81 & 18.53 & 4.31 \\
\hline 4 & Centenario 1 & 10.33 & 10.25 & 18.77 & 9.88 & 11.84 & \\
\hline
\end{tabular}

We considered all the possibilities for the cereal vessels. The vessels are unloaded in berths 3 and 4 of Centenario dock and the vessels can be loaded in the four feasible berths. The dock time of the vessels without cargo is independent of the gantry cranes because they are loaded by means of conveyor belts. For vessels with cargo we observed differences between the vessels arriving to Centenario dock and those arriving to Tablada dock, as can be viewed from table 6. The difference is due to the gantry crane performance. The difference exists also for berth 3 and 4 in the Centenario dock (berth 3 has a gantry crane with better performance).

Table 6. Dock time for cereal vessels

\begin{tabular}{|c|c|c|c|c|c|c|c|}
\hline \multirow{2}{*}{$\begin{array}{c}\text { Vessel } \\
\text { with } \\
\text { cargo }\end{array}$} & \multirow[b]{2}{*}{ Dock - Berth } & \multicolumn{4}{|c|}{ Number of replication } & \multirow{2}{*}{$\begin{array}{c}\text { Average } \\
\text { value }\end{array}$} & \multirow{2}{*}{$\begin{array}{l}\text { Standard } \\
\text { deviation }\end{array}$} \\
\hline & & $1^{\text {st }}$ & $2^{\text {nd }}$ & $3^{\text {rd }}$ & $4^{\text {th }}$ & & \\
\hline \multirow{2}{*}{$\mathrm{NO}$} & Centenario 3 & 16.17 & 17.5 & 15.79 & 20.14 & 17.32 & 1.97 \\
\hline & Centenario 4 & 16.17 & 17.5 & 15.79 & 20.14 & 17.32 & 1.97 \\
\hline \multirow{4}{*}{ YES } & Centenario 3 & 7.88 & 10.07 & 13.81 & 14.18 & 11.16 & 3.04 \\
\hline & Centenario 4 & 10.55 & 9.94 & 13.84 & 12.4 & 11.58 & 1.78 \\
\hline & Tablada 3 & 14.61 & 13.07 & 14.51 & 15.47 & 14.39 & 0.99 \\
\hline & Tablada 4 & 12.2 & 16.73 & 11.06 & 14.39 & 13.43 & 2.50 \\
\hline
\end{tabular}

The scrap vessels follow four possible destinations. Due to the difference between the performances of the cranes, the dock times in the North Batán berths are different from the Tablada dock ones. The iron and steel vessels are mainly assigned to the berth 5 of Centenario dock. On the other hand, the cement vessels are assigned to the berths next to the 'Asland' Company, which are the berths 1 and 2 of North Batán dock. Finally, the fertilizers vessels experience similar times for the different berths of the Tablada dock. Table 7 shows the results. 
Table 7. Dock time for the rest of cargo

\begin{tabular}{|c|c|c|c|c|c|c|c|}
\hline \multirow{2}{*}{ Cargo } & \multirow{2}{*}{ Dock - Berth } & \multicolumn{4}{|c|}{ Number of replication } & \multirow{2}{*}{$\begin{array}{c}\text { Average } \\
\text { value }\end{array}$} & \multirow{2}{*}{$\begin{array}{l}\text { Standard } \\
\text { deviation }\end{array}$} \\
\hline & & $1^{\text {st }}$ & $2^{\text {nd }}$ & $3^{\text {rd }}$ & $4^{\text {th }}$ & & \\
\hline \multirow{4}{*}{ Scrap } & Batán 4 & 15.76 & 20.75 & 17.97 & 18.15 & 18.07 & 2.04 \\
\hline & Tablada 6 & 9.68 & 14.06 & 9.71 & 13.4 & 11.54 & 2.35 \\
\hline & Batán 3 & 17.34 & 19.12 & 15.51 & 19.51 & 17.80 & 1.84 \\
\hline & Tablada 5 & 6.82 & 12.64 & 12.02 & 14.81 & 11.13 & 3.39 \\
\hline \multirow{4}{*}{ Iron and steel } & Centenario 5 & 16.9 & 24.58 & 20.8 & 27.1 & 22.00 & 4.46 \\
\hline & Centenario 4 & 13.53 & 14.47 & 13.58 & 11.81 & 13.31 & 1.11 \\
\hline & Batán 3 & 18 & 20.94 & 15.93 & 21.72 & 19.00 & 2.68 \\
\hline & Tablada 5 & 12.07 & 14.63 & 11.33 & 14.51 & 13.05 & 1.69 \\
\hline \multirow{2}{*}{ Cement } & Batán 1 & 22.2 & 30.11 & 22.77 & 31.97 & 26.41 & 5.00 \\
\hline & Batán 2 & 22.17 & 25.23 & 22.98 & 33.28 & 25.57 & 5.08 \\
\hline \multirow{3}{*}{ Fertilizers } & Batán 2 & 14.44 & 18.44 & 14 & 15.1 & 15.40 & 2.01 \\
\hline & Tablada 1 & 11.31 & 13.07 & 14.41 & 15.47 & 13.47 & 1.80 \\
\hline & Tablada 2 & 9.37 & 16.73 & 13.03 & 14.39 & 13.09 & 3.08 \\
\hline
\end{tabular}

\subsection{Real traffic analysis}

We simulate real traffic conditions for an arrival time distribution with mean 13 hours and standard deviation equal to 2 hours. This traffic corresponds to the arrival of 223 vessels each 4 months. The simulation period is 90 days. The simulation provided results from 166 vessels berthed in the Port of Seville. Next table 8 describes the results of system time and dock time.

Table 8. Vessel time in real traffic simulated

\begin{tabular}{|l|c|c|c|}
\hline \multicolumn{1}{|c|}{ Variable } & Average time & Maximum Time & Standard deviation \\
\hline Vessel system time & 34.55 & 117.40 & 12.38 \\
\hline Berth 1 of Centenario dock & 21.11 & 69.32 & 11.21 \\
\hline Berth 2 of Centenario dock & 24.58 & 109.74 & 20.1 \\
\hline Berth 3 of Centenario dock & 18.21 & 28.08 & 3.81 \\
\hline Berth 4 of Centenario dock & 16.21 & 31.24 & 3.34 \\
\hline Berth 5 of Centenario dock & 23.5 & 30.18 & 5.65 \\
\hline Berth 1 of North Batán dock & 30.1 & 39.83 & 5.01 \\
\hline Berth 2 of North Batán dock & 19.58 & 38.34 & 0 \\
\hline Berth 3 of North Batán dock & 23.61 & 23.61 & 2.91 \\
\hline Berth 4 of North Batán dock & 21.3 & 25.81 & 0 \\
\hline Berth 1 of Tablada dock & 11.99 & 11.99 & 0.84 \\
\hline Berth 2 of Tablada dock & 0 & 0 & 0 \\
\hline Berth 3 of Tablada dock & 14.96 & 16.21 & 0 \\
\hline Berth 4 of Tablada dock & 0 & 0 & 1.51 \\
\hline Berth 5 of Tablada dock & 0 & 0 & 15.54 \\
\hline Berth 6 of Tablada dock & 13.06 & & \\
\hline
\end{tabular}

Looking at the values we find scarce variation between the maximum and average values except for berth 1 and 2 in the Centenario dock. This phenomenon is due to the high traffic of container vessels having only two berths at their disposal, at difference from the rest of cargo vessels. These aspects can also be viewed in the queues analysis (see table 9). This container effect provided a great maximum value for the vessel system time; however the average value is adequate for the logistic operation and we observed that most of the values were found around the mean. On the other hand, we experienced no berths in the Tablada dock (berths 2, 4 and 5) due to the traffic with destination the Tablada dock, in the period simulated. Table 9 
presents the statistics for the queues in the lock and in the Centenario dock. The rest of docks did not make queues.

Table 9. Queue size in real traffic simulated

\begin{tabular}{|l|c|c|}
\hline \multicolumn{1}{|c|}{ Queue } & Maximum value & Queue waiting time \\
\hline Lock arrival & 1 & 0.35 \\
\hline Lock exit & 1 & 0.35 \\
\hline Berth 1 of Centenario dock & 1 & 13.88 \\
\hline Berth 2 of Centenario dock & 1 & 12.97 \\
\hline
\end{tabular}

The berths 1 and 2 of the Centenario dock are the only berths with queues. The lock generates scarce queues, but we have to conclude that the lock do not limit the logistic operation of the port. However, the lock cuts down the size of the vessels arriving the Seville Port, so it must be had in account. The rest of resources: coastal pilots and mooring rope workforce do not offer the presence of queues.

Table 10 presents the capacity level in the warehousing facilities of the port.

Table 10. Warehousing facilities capacity level

\begin{tabular}{|l|c|c|c|}
\hline \multicolumn{1}{|c|}{ Variable } & Average value & Maximum value & \% of occupation \\
\hline Batán warehouse & $6,492.95$ & 14,620 & 18 \\
\hline Centenario warehouse & $6,513.29$ & 11,800 & 13 \\
\hline Uncovered warehouse of Tablada & $2,079.88$ & 4,300 & 6 \\
\hline Tablada sheds & $5,975.67$ & 10,240 & 5 \\
\hline Cement & $4,264.42$ & 12,674 & 28 \\
\hline Cereals in silos & $5,017.2$ & 8,015 & 42 \\
\hline Containers - Contenemar & 461 & 977 & - \\
\hline Containers - TMS & 584 & 1,289 & - \\
\hline Containers - Pinillos & 742 & 1,453 & - \\
\hline
\end{tabular}

Table 10 allows us to affirm that the maximum capacity level of the warehousing facilities is never reached. Even the level of occupation is quite low, especially for the uncovered warehousing facilities and the sheds. The major level of occupation is found in the cereal silos and in the cement warehouses, but the capacity is still bounded. The number of containers in the container terminal is adequate for the available surface for the logistic operation.

Table 11 shows the lorry traffic in the port dependencies.

Table 11. Real lorry traffic simulated

\begin{tabular}{|l|c|c|}
\hline \multicolumn{1}{|c|}{ Counter } & Value & Daily lorries \\
\hline Cement lorries & 2,481 & 28 \\
\hline Cereals lorries & 2,728 & 30 \\
\hline Container lorries (Contenemar) & 7,719 & 86 \\
\hline Container lorries (TMS) & 10,968 & 122 \\
\hline Container lorries (Pinillos) & 12,237 & 136 \\
\hline
\end{tabular}

The daily number of lorries of cement and cereals is common and reasonable. This is because the capacity of the facilities has not been surpassed. In fact, the programme has been designed for considering an arrival of lorries guaranteeing the capacity of the warehousing facilities under the maximum. On the contrary, the arrival of lorries at the container terminal is greater due to a higher requirement from these facilities. Furthermore, the existence of a high number 
of lorries transporting cargo is also due to the conversion factor TEU - container (1.35 TEUs/container and currently most of the containers are 2 TEUs). In fact, this is precisely one of the advantages of the maritime traffic.

\section{Conclusions and final remarks}

This paper has described the main simulation results of the logistic activity carried out in the Seville inland port. The port characteristics, including both the maritime and logistic ones, and an in depth description of the system simulation modules has been presented.

From the analysis of the results on this paper, we can conclude that the port facilities are able to cope with the current incoming logistic flows, except for temporary difficulties in the container traffic. Therefore, the increase of the logistic business volume must come from the commercial activity, especially in new and emergent markets, as well as the improvement of the access infrastructures of the Guadalquivir estuary. The infrastructure activities should include the dredging of the estuary to increase its depth and the substitution of the lock for another one of greater dimensions that allows the arrival of bigger vessels.

\section{Acknowledgements}

The authors acknowledge the financial support given to the research presented in this paper by both the Dirección General de la Marina Mercante del Ministerio de Fomento de España and the Ministerio de Educación y Ciencia de España (Spanish Ministry of Education and Science) through its Transport Research Programme (Project ref.: TRA2006-15423-C04-01)

Additionally, we would like to acknowledge the personal collaboration given by Mr. Manuel Fernández González and Mr. Fausto Arroyo Crejo, President and General Manager of the Port Authority of Seville respectively, as well as the technical support given by Mr. Jesús González Ramírez, General Manager of Serviport Andalucía S.A.

\section{References}

[1] Y. Merkuryev, J. Tolujew, E. Blümer, L. Novitsky, E. Ginters, E. Vitorova, G. Merkuryeva and J. Pronins, A modelling and simulation methodology for managing the Riga Harbour container terminal, Simulation 71- 2 (1998) 84-95.

[2] Y. Merkuryev, F. Kamperman, V. Visipkov and A. Smits, ARENA-based simulation of logistics processes at the Baltic container terminal, in: Proc.14th European Simulation Multi-conference - Simulation and Modelling: Enablers for a Better Quality of Life (2000) 433-437.

[3] G. Merkuryeva, Y. Merkuryev and J. Tolujev, Computer Simulation and Metamodelling of Logistics Processes at a Container Terminal, Studies in Informatics and Control, 9 - 1 (2000) art. 06.

[4] A. Bruzzone and R. Signorile, Simulation and genetic algorithms for ship planning and shipyard layout, Simulation 71 - 2 (1998) 74-83

[5] M.B. Silberholz, B.L. Golden and E.K. Baker, Using simulation to study the impact of work rules on productivity at marine container terminals, Journal of Operational Research Society, 46 (1991) 1090-1101.

[6] L.M. Gambardella, A. Rizzoli and M. Zaffalon, Simulation and planning for intermodal container terminal, Simulation 71 - 2 (1998) 107-116 
[7] K.H. Kim and H.B. Kim, Segregating space allocation models for container inventories in port container terminals, International Journal of Production Economics 59 1-3 (1999) 415-423.

[8] M. Mastrolilli, N. Fornara, L.M. Gambardella, A.E. Rizzoli and M. Zaffalon, Simulation for policy evaluation, planning and decision support in an intermodal container terminal, in: Proc. of the International Workshop "Modeling and Simulation within a Maritime Environment", Y. Merkuryev, A. Bruzzone, L. Novitsky, eds. Society for Computer Simulation International (1998) 33-38.

[9] E. Köse, E. Basar, E. Demirci, A. Günerglu and S. Erkebay, Simulation of marine traffic in Istanbul Strait, Simulation Modelling Practice and Theory 11 (2003) 597608.

[10] Y. Hayuth, M.A. Pollatschek, M.A. and Y. Roll, Building a port simulator, Simulation 63 - 3 (1994) 179-189

[11] Puerto de Sevilla, Manual de Procedimientos PGC 4.01. Procedimientos Operativos de Calidad, 2002.

[12] Puerto de Sevilla, Plan Director del Puerto de Sevilla, 2001.

[13] Puerto de Sevilla, Memoria anual. Informe de gestión para 2003, 2004. 